\title{
Da Palavra sai vida e morte: estudo exegético de 2 Rs 2,19-25
}

\author{
Orientadora: Maria de Lourdes Corrêa Lima \\ Mestrando: Doaldo Ferreira Belem \\ Área de Concentração: Teologia Bíblica
}

Linha de Pesquisa: Análise e Interpretação de Textos do Antigo e Novo Testamento

O presente trabalho analisa na perícope de 2 Rs 2,19-25 o tema do poder paradigmático em dar vida e tirá-la, abençoar e amaldiçoar no ministério de Eliseu. Não somente busca evidenciar a função desta perícope como uma unidade, mas também como introdução a todo o ciclo de Eliseu, o qual lidou no seu ministério com o poder de abençoar os obedientes e que respeitam o profeta como genuíno representante de YHWH, e o poder de amaldiçoar aqueles que se lhe opõem. Utilizando o Método Histórico-Crítico e a Análise Narrativa, será evidenciada em 2Rs 2,19-25 uma mesma trama em dois episódios, servindo de conclusão da seção que engloba todo o conjunto de 2Rs 2 numa trama unificada. Eliseu é o herói dessa narrativa, o qual tem como objetivo enquanto discípulo tornar-se mestre, o sucessor de Elias; e as simetrias com 2Rs 1 fazem de 2Rs 1-2 a narrativa de sucessão profética de Eliseu moldada à sucessão mosaica.

Palavras-chave: Profeta Eliseu. Livros dos Reis. Profetismo. Narratologia. 